\title{
NRG2 Gene Product
}

National Cancer Institute

\section{Source}

National Cancer Institute. NRG2 Gene Product. NCI Thesaurus. Code C118415.

A protein encoded by the NRG2 gene. 